\title{
PENGEMBANGAN BUKU AJAR PENDIDIKAN JASMANI BAGI ANAK USIA DINI
}

\author{
Fadli Surahman ${ }^{* 1}$, Rahmat Sanusi ${ }^{2}$, Tisrin Maulina Dewi ${ }^{3}$ \\ Universitas Karimun, Indonesia ${ }^{* 123}$ \\ Email: fadlisurahman89@yahoo.com ${ }^{* 1}$, rahmatsanusi25@gmail.com ${ }^{2}$, \\ tisrinmaulinadewi@gmail.com ${ }^{3}$
}

Received: 8 April 2020; Accepted 23 July 2020; Published 18 November 2020

Ed 2020; 5(2): 116-127

\begin{abstract}
ABSTRAK
Permasalahan dalam penelitian ini yaitu ketersedian buku ajar pembelajaran pendidikan jasmani untuk PAUD atau buku pedoman bagi guru olahraga di sekolah masih belum ada, dalam pembelajaran sebelumnya masih menggunakan buku pendidikan jasmani secara umum. Penelitian ini bertujuan untuk menghasilkan buku ajar pendamping bagi guru di sekolah PAUD dan TK dalam pembelajaran pendidikan jasmani kesehatan dan rekreasi. Penelitian ini merupakan penelitian pengembangan yang mengacu pada konsep pengembangan Borg dan Gall yang dipersingkat menjadi tujuh langkah yang disesuaikan dengan kebutuhan. Uji coba skala kecil melibatkan 10 orang subjek pengguna dan uji coba skala besar melibatkan 35 orang subjek penggunaan. Agar produk yang dihasilkan dapat dinyatakan valid maka dalam penelitian ini melibatkan tiga validator yang terdiri dari ahli motorik, ahli pembelajaran pendidikan jasmani dan ahli pembelajaran pendidikan anak usia dini. Dari hasil uji coba skala kecil dari validasi ahli diperoleh rata-rata penilaian diperoleh skor 3.5 dengan kategori "Baik" dan hasil uji coba skala besar dari validasi ahli diperoleh nilai rata-rata sebesar 3.9 dengan kategori "Baik". Berdasarkan penilaian tersebut maka dapat disimpulkan bahwa produk buku pembelajaran pendidikan jasmani bagi anak usia dini dinyatakan layak untuk digunakan. Untuk penelitian selanjutnya dapat dilakukan efektifitas buku ajar yang sudah dikembangkan sehingga dapat melihat seberapa besar pengaruh buku ajar ini dalam pembelajaran pendidikan jasmani PAUD.
\end{abstract}

Kata Kunci: Buku Ajar; Usia Dini; Pendidikan Jasmani

\section{DEVELOPING TEXTBOOK PHYSICAL EDUCATION FOR CHILDHOOD}

\begin{abstract}
The problem in this research is the availability of textbook teaching physical education for early childhood or manual for sports teachers in schools is still there, in the previous learning still uses the book physical education in general. The aim of this research is generating a guide text book for teacher at PAUD and Kindergarten in physical education and recreation learning. This study is the research of development that refers from Borg and Gall concept which is shortened to seven steps as needed. Smallscale testing involves 10 subjects and field testing involves 35 subjects. In order the resulting product can be valid so in this study involves three validators consisting of motor experts, physical education learning experts and early childhood education learning experts. From the result of small-scale trials of expert validation is obtained an average score of 3.5 with the category of "Good" and large-scale trial result of expert validation is obtained an average score of 3.9 with the category of "Good". Based on this assessment, it can be concluded that product of physical education learning textbooks for early childhood are considered suitable for used. For further research can be conducted effectiveness of textbooks that have been developed so that they can see how much influence this textbook in PAUD physical education learning.
\end{abstract}

Keywords: Book Text; Eearly Childhood; Physical Education

Copyright (C) 2020, Journal Sport Area

DOI: https://doi.org/10.25299/sportarea.2020.vol5(2).4797

How To Cite: Surahman, F., Sanusi, R., \& Dewi, T. M. (2020). Pengembangan Buku Pembelajaran Pendidikan Jasmani Bagi Anak Usia Dini. Journal Sport Area, 5(2), 116-127. 


\section{PENDAHULUAN}

Melalui Undang-Undang Sistem Keolahragaan Nasional No. 3 Tahun 2005 pada pasal 3 ayat 2 menekankan bahwa pelaksanaan olahraga pendidikan dimulai pada usia dini. Pelaksanaan pendidikan olahraga dimulai sejak usia dini guna membentuk pertumbuhan fisik dan perkembangan emosi anak. Usia dini merupakan fase penting dalam tumbuh kembang anak. Secara umum anak usia dini dikategorikan dari usia 2-8 tahun. Secara spesifik, tingkatan anak usia dini berdasarkan jenjang pendidikan. Pendidikan nonformal seperti kelompok bermain pendidikan anak usia dini yang dimulai dari umur 2 hingga 4 tahun. Pendidikan formal untuk taman kanak-kanak yaitu usia 4-5 tahun dan sekolah dasar kelas kecil pada kelas 1 sampai kelas 2. Karatekteristik pada fase ini adalah proses eksplorasi keingintahuan akan hal-hal baru dimana anak dengan cepat mencontoh dan menerima berbagai perbandingan. Terutama pada fase 4-5 tahun yang merupakan fase emas untuk menanamkan nilai-nilai karakter, salah satunya adalah menanamkan nilai-nilai positif pendidikan jasmani.

Pendidikan jasmani dapat diartikan sebagai pendidikan yang dilaksanakan melalui aktivitas fisik. Menurut Dyson (2014) menyatakan standar pertama dalam pembelajaran pendidikan jasmani adalah siswa dapat menunjukkan kompetensi dalam berbagai keterampilan motorik dan pola gerak. Standar berikutnya adalah aktif secara fisik. Konsep pengajaran standar ini adalah cita-cita yang berharga, untuk itu perlu mendorong para guru agar dapat mencapai standar pembelajaran tersebut. Rink dalam Dyson (2014) menjelaskan bahwa standar umum pembelajaran pendidikan jasmani dirancang untuk mengembangkan gaya hidup aktif secara fisik pendidikan yang bertujuan untuk mengembangkan secara maksimal kemampuan fisik, mental, integrasi sosial dan individu melalui aktivitas fisik dan olahraga.

Pendapat para ahli yang yang dikemukan di atas sejalan dengan pendapat Schwamberger dan Sinelnikov (2015) menyatakan bahwa menyusun tujuan utama pembelajaran pendidikan jasmani adalah meningkatkan partisipasi aktivitas fisik yang menekankan keterampilan dan pengetahuan yang berkaitan dengan melakukan aktivitas fisik secara aktif di sekolah atau luar sekolah, gaya hidup dan kesehatan. peserta didik. Pelana (2014) menambahkan pengertian pendidikan jsamani merupakan bagian yang esensial dan integral dalam pendidikan holistik yang bertujuan untuk mengembangkan aspek kesehatan, kebugaran jasmani, keterampilan berfikir kritis, kestabilan emosional, keterampilan sosial, alasan dan tindakan moral melalui aktivitas fisik dan olahraga. Berdasarkan paparan di atas dapat disimpulkan bahwa pendidikan jasmani merupakan pembelajaran yang dilaksanakan dengan melibatkan fisik untuk tercapainya kebugaran jasmani, keterampilan, perkembangan intelektual dan membangun kepekaan/kecakapan sosial.

Pembelajaran pendidikan jasmani bukan hanya tentang permainan dan bola. Terdapat empat tujuan utama dalam pembelajaran pendidikan olahraga untuk peserta didik termasuk didalamnya pendikan jasmani bagi anak usia dini. Menurut Pill (2011) ada empat tujuan utama dari pendidikan jasmani: yaitu (1) pendidikan organikpengembangan otot dan kekuatan skeletal, (2) pendidikan psikomotor-pengembangan keterampilan dalam kegiatan neuromuskuler, (3) pendidikan karakter-pengembangan karakter moral, sosial, dan pribadi, dan (4) pendidikan intelektual perkembangan kognitif, pengetahuan ekspresif. Tujuan pendidikan jasmani di atas meliputi pendidikan organ, pendidikan gerak, pendidikan karakter, dan pendidikan kecerdasan. Pendidikan organ mengembangan otot dan tulang melalui aktivitas. Pendidikan gerak mengembangkan keterampilan dalam melakukan aktivitas jasmani. Pendidikan karakter 
bertujuan untuk mengembangkan moral, sosial, dan karakter pribadi. Herdiyana dan Prakoso (2016) menekan pendidikan kecerdasan bertujuan untuk mengembangkan kemampuan kognitif siswa. Metzler dalam Dyson, Linehan, dan Hastie (2010) mengungkapkan bahwa pembelajaran pendidikan jasmani memiliki salah satu ciri khas yaitu cooperatif learning yang menekankan pada budaya olahraga sebagai tujuannya melalui aktivitas fisik, kebugaran, pola hidup yang dikembangkan baik secara fisik maupun mental.

Pembelajaran secara umum dalam semua tingkatan pendidikan memiliki tujuan yang sama yaitu meningkatkan kebugaran jasmani namun secara khusus tujuan pembelajaran pendidikan jasmani memiliki peran dan tujuan berbeda pada setiap jejang pendidikan, termasuk pembelajaran pendidikan jasmani pada jenjang Pendidikan Anak Usia Dini. Anak usia dini secara umum masuk pada usia 0-8 tahun. Menurut Hermawan (2011) usia dini yang lazim diartikan pada kisaran 0-8 tahun memang merupakan usia yang sangat menentukan dalam pembentukan karakter dan pengembangan intelegensi seorang anak. Dini (2017) menjelaskan bahwa pendidikan anak usia dini adalah anak yang berusia 0-6 bulan. Melalui pendidikan nasional, klasifikasi anak usia dini dini dibagi berdasarkan jenjang pendidikan yaitu lembaga pendidikan usia dini (PAUD)/ lembaga bermain pada usia 2-4 tahun dan Taman Kanak-kanak usia 4-5 tahun. Paparan di atas menyebutkan secara umum rentang umur anak usia ini dapat digolongkan dari umur 0-8 tahun dan secara khusus dapat diklasifikasikan berdasarkan jenjang pendidikan PAUD dan TK.

Pembelajaran pendidikan jasmani menekankan pada proses pembinaan pertumbuhan dan perkembangan dasar. Pertumbuhan berkaitan dengan fisik (fisiologis) dan perkembangan berkaitan aspek psikologis. Pada tahap pertumbuhan, pembelajaran pendidikan jasmani pada PAUD difokuskan pada kemampuan motorik yang mana kemampuan motorik berkaitan dengan keterampilan gerak yang melibatkan keseluruhan organ tubuh. Aktivitas fisik dan olahraga merupakan bentuk dari pengembangan gerak motorik dasar. Tanpa gerak motorik dasar yang baik, maka gerakan pengembangannya tidak dapat tercapai optimal. Gerak adalah bagian penting untuk mendukung aktivitas Anak Usia Dini (AUD). Ma'mun dan Saputra dalam Hermawan (2011) mengartikan bahwa perilaku gerak menekankan pada prinsip-prinsip keterampilan gerak manusia yang dihasilkan pada tahap perilaku analisis. Sejalan dengan aktivitas fisik dalam pendidikan jasmani yang mengaitkan keterampilan gerak melalui olahraga dimana makna olahraga itu sendiri adalah serangkaian gerak yang teratur dan terencana.

Clarke dan Kinchin (2005) menjelaskan bahwa aktivitas fisik merupakan alat prediksi yang tepat untuk melihat level akitivitas yang dilakukan oleh AUD. Aktivitas fisik seperti berlari, melompat dan lain sebagainya melibatkan penggunaan oksigen yang dapat dikategorikan sebagai olahraga aerobik. Best (2010) menyatakan bahwa latihan aerobik dengan intensitas sedang dan tinggi digunakan sebagai media promosi kepada anak-anak untuk meningkatkan kognitif dan perilaku dan hal terpenting adalah meningkatkan kesehatan. Membangun kesadaran pentingnya hidup sehat dengan melakukan aktivitas fisik menjadi dasar penting untuk ditanam peserta didik AUD melalui pembelajaran pendidikan jasmani.

Menanamkan nilai-nilai karakter menjadi prinsip penting yang harus ditanamkan sejak usia dini melalui pembelajaran pendidikan jasmani. Pembelajaran pendidikan jasmani menanamkan nilai-nilai karakter yang menjadi pondasi dalam olahraga. Pendidikan jasmani merupakan pembelajaran penting yang menjadi keharusan untuk ambil bagian dalam kurikulum disemua jenjang pendidikan. Dalam olahraga terdapat 
nilai-nilai penting yang memiliki karateristik tertentu sesuai dengan cabang olahraga. Misalnya, olahraga yang sifatnya tim/regu atau kelompok seperti sepakbola dan basket mengajarkan peserat didik untuk dapat bekerjasama, kompak dan memiliki kesamaan tujuan yang hendak dicapai. Kemenangan yang diperoleh bukan hasil kerjas keras satu orang melainkan semua orang dalam tim terintegrasi dan saling membantu. Untuk olahraga yang sifatnya individu seperti karate, silat membentuk karakter yang berani, tidak mudah menyerah dan mengakui kemenangan orang lain dan sportif.

Mengoptimalkan peran dan fungsi pendidikan olahraga pada anak usia dini melalui pendidikan formal atau non formal menjadi salah satu upaya untuk menanamkan nilainilai karakter bukan hanya melalui pemahaman namun melalui implementasi nyata. Berdasarkan observasi dan wawancara dengan guru PAUD di beberapa sekolah TK dan lembaga Pendidikan Anak Usia Dini (PAUD) ditemui masih terbatasnya SDM dengan latar belakang pendidikan olahraga. Hampir di semua sekolah TK dan PAUD tidak memiliki guru pendidikan jasmani dengan latar belakang pendidikan pendidikan jasmani. Wawancara dengan Bapak Ernaidi, S.Pd mengatakan ketersedian buku ajar pembelajaran pendidikan jasmani untuk PAUD atau buku pedoman bagi guru olahraga di sekolah masih belum ada, dalam pembelajaran sebelumnya masih menggunakan buku pendidikan jasmani secara umum. Dengan keterbatasan latar belakang bukan pendidikan olahraga, pemahaman tentang pendidikan olahraga hanya di dapat melalui pelatihan, modul dan buku ajar secara umum sehingga pemahaman guru tentang prinsip-prinsip dasar pendidikan olahraga pada anak usia dini tidak tercapai optimal.

Buku ajar menjadi bahan penting dalam memberikan pembelajaran sebagai pedoman bagi guru dalam membuat, menyusun dan merumuskan kedalaman materi untuk disajikan kepada peserta didik. Tercapainya hasil belajar salah satunya didukung dengan ketersediaan buku ajar. Buku ajar berisikan ke dalam ilmu yang diturunkan ke dalam bahan kajian. Ketersediaan buku ajar dianggap yang digunakan sebagai buku pelajaran dalam bidang studi penting karena merupakan buku pendamping dan menjadi acuan bidang studi tertentu. Surahman dan Yeni (2019) mengungkapkan bahwa buku ajar dan proses belajar memiliki hubungan yang saling berkaitan agar materi yang disampaikan oleh pengajar dapat disampaikan dengan efektif. Adalikwu dan Iorkpilgh (2013) menyatakan bahwa bahan ajar berperan sebagai fasilitator antara pendidik dengan peserta didik dan mengembangkan motivasi peserta didik selama kegiatan pembelajaran. Irwansyah (2018) memperkuat pengertian buku ajar sebagai media pembelajaran yang merupakan salah satu bentuk sumber belajar bagi guru atau dosen yang disusun secara sistematis oleh ahli bidang studi tertentu dalam hal ini profesi guru atau dosen, menurut kaidah-kaidah perancangan dengan tujuan meningkatkan efektifitas dan meningkatkan ketertarikan pembelajar untuk terus belajar. Buku ajar merupakan suatu kesatuan unit pembelajaran yang berisi informasi, pembahasan serta evaluasi. Buku ajar yang tersusun secara sistematis akan mempermudah peserta didik dalam memahami materi, sehingga sangat mendukung ketercapaian tujuan pembelajaran. Tujuan pengembangan ini adalah untuk mengembangkan buku ajar atau buku pedoman bagi guru pendidikan jasmani di sekolah TK dan PAUD. Buku yang dikembangkan nantinya berisikan materi tentang pembelajaran pendidikan jasmani untuk anak usia dini dengan kedalam materi yang lengkap dan spesifik.

\section{METODE PENELITIAN}

Penelitian ini merupakan penelitian pengembangan dengan pendekatan Research \& Development yang dikembangkan oleh Borg \& Gall yang dikutip dari Suharnoko dan 
Firmansyah (2018) yang terdiri dari 10 langkah pengembangan. Dalam penelitian ini, penulis mempersingkat langkah-langkah pengembangan menjadi 7 langkah yang disesuaikan dengan kebutuhan dan keterbatasan penulis. Adapun 7 langkah tersebut terdiri dari: Langkah ke-1, mengumpulkan informasi dan menentukan potensi masalah. Pada langkah ini penulis mencari sebanyak mungkin informasi yang berhubungan tentang proses pembelajaran di pendidikan anak usia dini, baik itu sekolah PAUD dan TK. Semakin banyak informasi yang diperoleh maka semakin besar potensi masalah yang akan ditemukan. Dalam pengumpulan informasi penulis melakukan kegiatan observasi yang mengacu pada pengamatan secara langsung dan melakukan wawancara. Langkah ke-2, analisa informasi dan perencanaan. Setelah informasi diterima, langkah selanjutnya adalah melakukan analisa informasi untuk mendapatkan potensi masalah yaitu belum tercapainya sasaran yang tepat dan tujuan yang jelas dalam proses kegiatan pembelajaran pendidikan jasmani bagi anak usia dini. Dengan demikian perencanaan difokuskan untuk memberikan solusi agar dalam pembelajaran pendidikan jasmani sasaran dan tujuannya menjadi tepat sasaran.

Langkah ke-3 adalah desain produk awal. Setelah menemukan potensi masalah dan selanjutnya menyusun rencana tentang pengembangan buku ajar pembelajaran pendidikan jasmani bagi anak usia dini. Produk yang dikembangkan diharapkan dapat menjadi solusi sebagai buku pendamping yang dapat membantu guru dalam proses pembelajaran pendidikan jasmani. Terdapat beberapa poin dalam penyusunan desain produk awal yaitu standar kompetensi inti dan kompetensi dasar, konten/isi serta rubrik evaluasi untuk mentukan ketercapaian proses pembelajaran pendidikan jasmani. Langkah ke-4, validasi dan perbaikan desain. Setelah produk selesai dirumuskan, langkah berikutnya adalah melakukan validasi. Validasi merupakan penyempurnaan produk yang dikembangkan agar dapat dinyatakan valid dengan melibatkan 3 validator yaitu, pertama Hida Oktri Yeni, S.Pd., M.Pd yang merupakan dosen ahli dibidang gerak motorik peserta didik yang akan menilai konten dan isi dari setiap meteri buku yang dikembangkan. Kedua, Anggri Dwi Nata, S.Pd., M.Pd yang merupakan dosen ahli di bidang pembelajaran Pendidikan Jasmani. Ketiga, Aisyah Sasmita. S.Pd., AUD yang merupakan ahli Pendidikan Anak Usia Dini.

Langkah ke-5 adalah uji coba skala kecil. Setelah tahapan validasi dilaksanakan, tahapan berikutnya adalah melakukan uji coba penggunaan produk dalam skala kecil. Uji coba coba produk skala kecil melibatkan 10 guru dari sekolah PAUD dan TK yang berada di Kabupaten Karimun. Tahapan ini dilakukan untuk mengetahui respon pengguna terhadap produk yang kembangkan. Dengan mengetahui respon pengguna, maka penulis dapat mengetahui kelemahan dan kelebihan produk yang dikembangkan. Langkah ke-6, uji coba skala besar. Uji coba skala besar dilakukan dengan melibatkan 35 orang guru PAUD dan TK. Tujuan dilakukannya uji coba skala besar tidak jauh berbeda dengan ujicoba skala kecil yaitu untuk memperkuat kelebihan produk sehingga produk dapat diakui kebenaran dan kebermanfaatannya. Langkah ke-7, pembuatan produk final. Langkah ini merupakan langkah terakhir yang dilakukan setelah serangkaian tahapan sebelumnya. Tahapan ini merupakan regeneralisasi produk, dengan harapan produk ini dapat digunakan oleh guru PAUD dan TK sebagai referensi/pedoman dalam pembelajaran pendidikan jasmani bagi anak usia dini.

Penelitian ini merupakan penelitian kualitatif dan kuantitatif. Data kualitatif diperoleh melalui obeservasi, wawancara, telaah pustaka dan masukan dari validator. data kuantitatif diperokeh berdasarkan hasil kuesioner yang diberikan kepada subjek pengguna dan validator. Kuesioner yang diberikan menggunakan menurut Sugiono 
dalam Rosidah dan Sumarni (2017) Skala likert dengan lima opsi jawaban yaitu nilai 5 untuk penilaian "baik Sekali", nilai 4 untuk penilaian "baik", nilai 3 untuk penilaian "sedang", nilai 2 untuk penilaian "rendah" dan nilai 1 untuk penilaian "rendah sekali".

Secara umum kuesioner penilaian berisikan pertanyaan-pertanyaan terkait produk yang dikembangkan yang terdiri dari kelayakan materi yang berisikan keabsahan atau kelayakan materi yang terdapat dalam buku ajar, penyusunan standar kompetensi, kompetensi dasar dan rubrik evaluasi. Kelayakan tampilan buku ajar yang berisikan tampilan cover, susunan setiap materi, penggunaan bahasa, jenis font, warna dan lain sebagainya.

Penelitian ini menggunakan teknik analisa deskriptif dengan konversi data dari kualitatif dikonversi menjadi kuantitatif dengan lima kategori penilaian yaitu skor 5 untuk nilai baik sekali, skor 4 untuk nilai baik, skor 3 untuk nilai cukup, skor 2 untuk nilai kurang dan skor 1 untuk nilai kurang sekali. Sukardjo dalam Sanusi \& Widiyanto (2018) yang dijelaskan pada tabel 1.

Tabel 1. Konversi Data Kualitatif Ke Kuantitatif Dengan Skala 5

\begin{tabular}{ccc}
\hline Data Kuantitatif & Rentang & Data Kualitatif \\
\hline 5 & $\mathrm{X}>\mathrm{Xi}+1,80 \mathrm{Sbi}$ & Sangat Baik \\
4 & $\mathrm{Xi}+0,06 \mathrm{Sbi}<\mathrm{X}<\mathrm{Xi}+1,80 \mathrm{Sbi}$ & Baik \\
3 & $\mathrm{Xi}-0,60 \mathrm{Sbi}<\mathrm{X} \leq \mathrm{Xi}+0,60 \mathrm{Sbi}$ & Cukup \\
2 & $\mathrm{Xi}-1,80 \mathrm{Sbi}<\mathrm{X} \leq \mathrm{Xi}-0,60 \mathrm{Sbi}$ & Kurang \\
1 & $\mathrm{X} \leq \mathrm{Xi}-1,80 \mathrm{Sbi}$ & Kurang Sekali \\
\hline
\end{tabular}

Sanusi \& Widiyanto (2018)

Melalui teknik analisa data tersebut, informasi kualitatif akan dikonversi menjadi kuantitatif sehingga memudahkan penulis untuk mengetahui kelebihan dan kekurangan produk buku ajar berdasarkan penilaian para ahli dan subjek pengguna. Dengan mengetahui kelebihan dan kekurangan produk akan memudahkan bagi penulis dalam melakukan proses revisi/evaluasi produk yang diharapkan pada tahapan akhir pembuatan produk final kebenaran dan kualitas produk dapat diterima.

\section{HASIL DAN PEMBAHASAN}

\section{Uji Coba Skala Kecil}

Penilaian uji coba produk diawali dengan uji coba skala kecil. Proses uji coba skala kecil bertujuan untuk mengetahui kelemahan dan kelebihan produk buku ajar berdasarkan penilaian pengguna dalam skala terbatas. Dalam proses ini penulis melibatkan 10 orang subjek pengguna yang merupakan guru PAUD dan TK. Untuk mendapatkan informasi dari pengguna penulis memberikan kueisioner yang berkaitan dengan produk buku ajar yang dikembangkan. Berdasarkan hasil uji coba skala kecil dari subjek pengguna diperoleh data pada tabel 2.

Tabel 2. Hasil Data Uji Coba Skala Kecil Berdasarkan Respon Pengguna

\begin{tabular}{ccccc}
\hline No & Interval & Kategori & f & $\%$ \\
\hline 1 & $>4.21$ & Sangat Baik & 1 & 10 \\
2 & $3.41-4.21$ & Baik & 5 & 50 \\
3 & $2.61-3.40$ & Cukup & 4 & 40 \\
3 & $1.80-2.60$ & Kurang & 0 & 0 \\
4 & $<1.79$ & Kurang Sekali & 0 & 0 \\
\hline
\end{tabular}


Hasil data pada tabel 2 diperoleh informasi sebanyak 1 orang memberikan penilaian "Baik Sekali" dengan persentase sebesar 10\%, 5 orang memberikan penilaian "Baik" dengan persentase sebesar $50 \%$ dan 4 orang memberikan penilaian "Cukup" dengan persentase sebesar 40\%. Untuk kategori "Kurang" dan "Kurang Sekali" tidak ada. Berdasarkan paparan tersebut secara umum produk telah dapat diterima namun untuk hasil optimal, produk perlu untuk dilakukan revisi dengan membaca masukan dari pengguna terhadap kelemahan dan kekurangan produk buku ajar ini. Untuk lebih jelas dapat dilihat pada grafik 1.

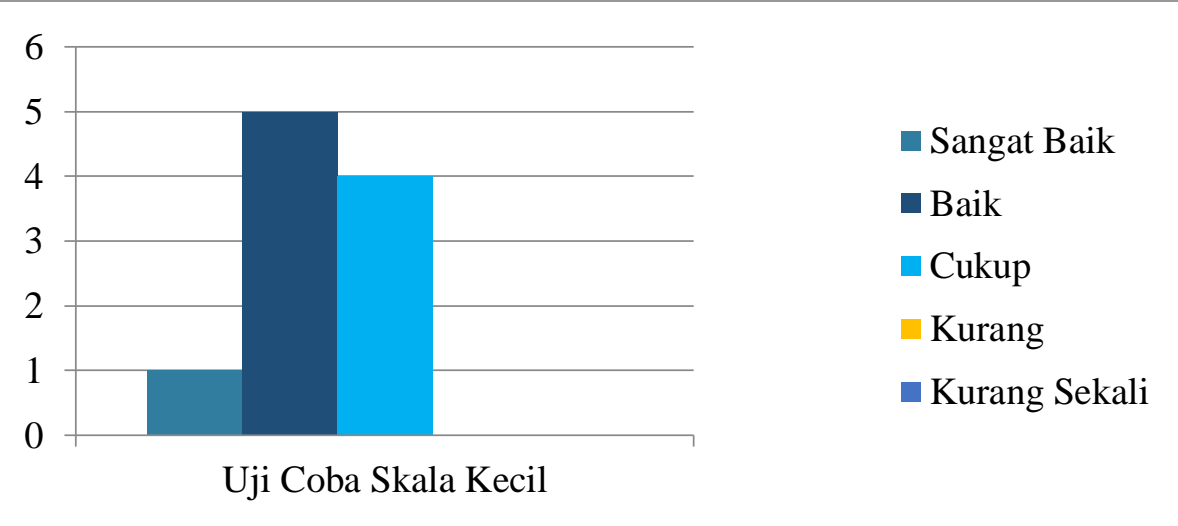

Grafik 1. Data Uji Coba Skala Kecil Berdasarkan Respons Pengguna

Tahapan berikutnya untuk mendapatkan informasi yang lebih lengkap terkait pengembangan produk adalah melakukan penilaian para ahli atau validator. Penilaian validor merupakan salah satu bagian penting dalam proses pengembangan produk ini. Masukan dan penilaian ahli menjadi dasar untuk menghasilkan sebuah produk yang valid sehingga kebenaran dan kegunaan produk dapat diterima secara luas. Melalui masukan dari para ahli memudahkan penulis untuk melakukan revisi/evaluasi terhadap produk agar semakin baik. Berikut diperoleh informasi berdasarkan penilaian validator pada tabel 3 .

Tabel 3. Hasil Data Berdasarkan Validasi Ahli Skala Kecil

\begin{tabular}{clcc}
\hline No & \multicolumn{1}{c}{ Validator } & Skor & Keterangan \\
\hline 1 & Ahli Materi & 3.3 & Cukup \\
2 & Ahli Pendidikan Jasmani & 3.6 & Baik \\
3 & Ahli Pembelajaran Anak Usia Dini & 3.7 & Baik \\
\hline \multicolumn{2}{r}{ Rata-Rata } & $\mathbf{3 . 5}$ & Baik \\
\hline
\end{tabular}

Hasil data pada tabel 3 di atas menunjukkan Ahli Materi memberikan penilaian sebesar 3.3 dengan kategori "Cukup", ahli pembelajaran pendidikan jasmani memberikan penilaian 3.6 dengan kategori "Baik" dan ahli pembelajaran anak usia dini memberikan penilaian sebesar 3.7 dengan kategori "Baik". Hasil rata-rata penilaian para ahli diperoleh skor sebesar 3.5 dengan kategori "Baik". Bedasarkan hasil data menunjukkan secara umum produk dapat digunakan namun untuk hasil yang lebih optimal perlu dilakukan revisi sebelum dilanjutkan ke tahapan uji coba skala besar. Untuk lebih jelas dapat dilihat pada grafik 2. 


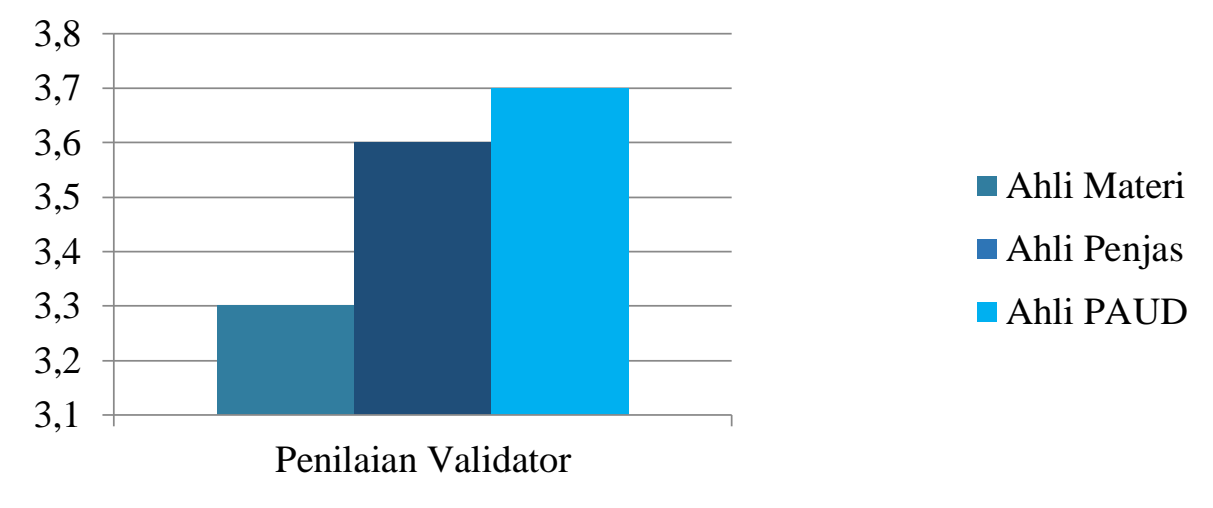

\section{Grafik 2. Data Uji Coba Skala Kecil Berdasarkan Validasi Ahli}

\section{Uji Coba Skala Besar}

Setelah uji coba skala kecil dilakukan, maka produk direvisi berdasarkan hasil penilaian pengguna dan validator agar produk menjadi lebih baik untuk diuji coba dalam skala besar. Uji coba skala besar dilakukan untuk mendapatkan informasi yang memastikan bahwa penerimaan produk dan kualitasnya menjadi lebih baik berdasarkan penilaian pengguna dan validator. Dalam uji coba skala besar ini mellibatkan subjek pengguna dengan jumlah yang lebih besar sebanyak 35 orang. Berdasarkan uji coba skala besar diperoleh data pada tabel 4.

Tabel 4. Hasil Data Uji Coba Skala Besar Berdasarkan Subjek Pengguna

\begin{tabular}{ccccc}
\hline No & Interval & Kategori & f & \% \\
\hline 1 & $>4.21$ & Sangat Baik & 9 & 25.7 \\
2 & $3.41-4.21$ & Baik & 26 & 74.3 \\
3 & $2.61-3.40$ & Cukup & - & - \\
3 & $1.80-2.60$ & Buruk & - & - \\
4 & $<1.79$ & Buruk Sekali & - & - \\
\hline & & & 35 & 100 \\
\hline
\end{tabular}

Dari paparan data pada tabel 4 di atas dapat dijelaskan sebanyak 9 orang memberikan penilaian "Sangat Baik" dengan persentase sebesar 25.7\%. Sebanyak 26 orang memberikan penilaian "Baik" dengan persentase sebesar 74.3\%. Untuk kategori "Cukup", "Buruk", dan "Buruk Sekali" tidak ada. Untuk lebih jelas digambarkan ke dalam grafik 3.

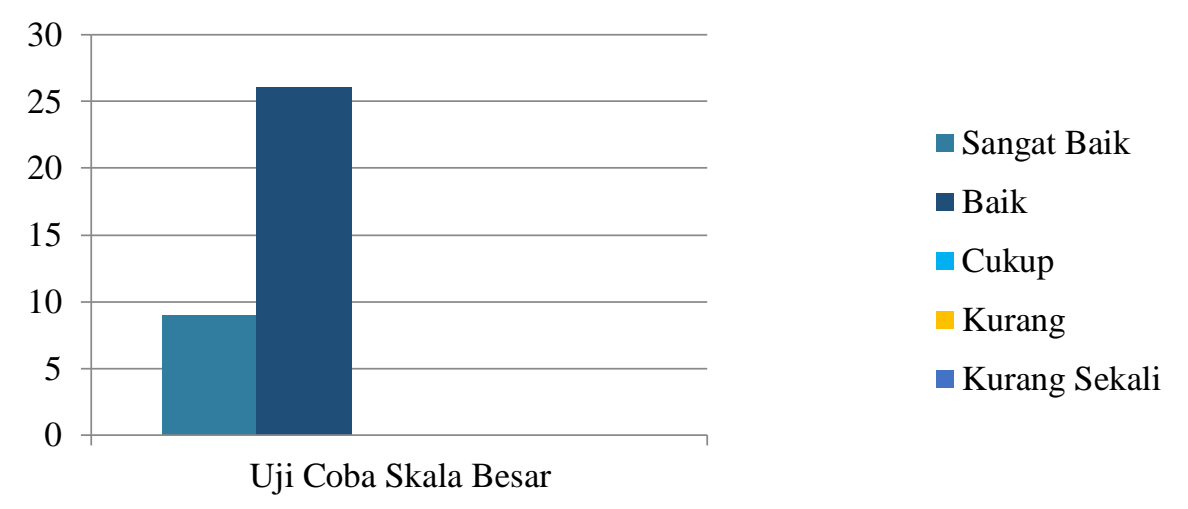

Gambar 3. Grafik Data Uji Coba Skala Besar Berdasarkan Subjek Pengguna 
Dari grafik 3 di atas dapat dilihat secara umum hasil uji coba skala besar menunjukkan data respons yang baik oleh pengguna terhadap produk buku ajar yang dikembangkan dengan peroleh rata-rata "Baik". Tahapan uji coba skala besar berikutnya adalah penilaian dari validator untuk memperkuat validitas dan kebermanfaatan produk buku ajar yang dikembangkan. Berikut disajikan data hasil penilaian validator pada tabel 5 .

Tabel 5. Hasil Data Uji Coba Skala Besar Berdasarkan Validasi Ahli

\begin{tabular}{clcc}
\hline No & \multicolumn{1}{c}{ Validator } & Skor & Kategori \\
\hline 1 & Ahli Materi & 4.0 & Baik \\
2 & Ahli Pendidikan Jasmani & 4.3 & Sangat Baik \\
3 & Ahli Pembelajaran Anak Usia Dini & 3.9 & Baik \\
\hline \multicolumn{2}{r}{ Rata-Rata } & $\mathbf{4 . 1}$ & Baik \\
\hline
\end{tabular}

Berdasarkan tabel 5 di atas dapat dilihat ahli materi memberikan skor sebesar 4.0 dengan kategori "Baik", ahli pendidikan jasmani memberikan skor sebesar 4.3 dengan kategori "Sangat Baik", dan Ahli pembelaja ran dan pendidikan anak usia dini memberikan skor sebesar 3.9 dengan kategori "Baik". Dari hasil tersebut diperoleh nilai rata-rata sebesar 4.1 dengan kategori "Baik". Untuk lebih jelas dapat dilihat pada grafik 4.

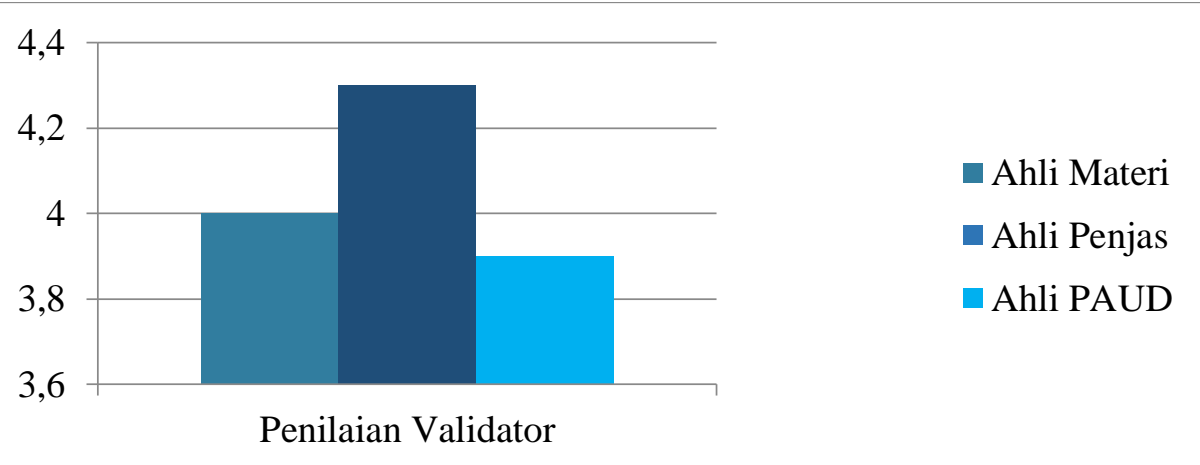

Grafik 4. Data Uji Coba Skala Besar Berdasarkan Validasi Ahli

Melihat keseluruhan paparan data yang telah disajikan dapat diambil sebuah kesimpulan bahwa produk yang dikembangkan dari sisi pengguna dan validasi ahli dinyatakan layak untuk digunakan sebagai buku pendamping dan panduan guru dalam proses pembelajaran pendidikan jasmani di jenjang pendidikan sekolah anak usia dini.

Penelitian ini mempunyai tujuan untuk menghasilkan sebuah produk buku ajar pembelajaran pendidikan jasmani anak usia dini, sehingga buku ajar ini bisa digunakan oleh guru sebagai pedoman dalam membuat, menyusun, dan merumuskan ke dalam materi yang akan disajikan. Buku ajar ini berisikan materi tentang pembelajaran pendidikan jasmani anak usia dini dengan kedalaman materi yang lengkap dan spesifik sehingga dalam penyajian materi akan lebih optimal sesuai dengan capaian kurikulum untuk anak usia dini.

Pembelajaran pendidikan jasmani memiliki peran yang krusial dalam membantu tumbuh kembang anak usia dini, meningat dalam fase ini keterlibatan aktivitas fisik sangat membantu dalam memperbaiki keterampilan motorik khususnya kemampuan motorik dasar seperti berjalan, berlari, melempar dan menangkap. Selain keterampilan motorik, pendidikan jasmani ikut membantu anak usia dini dalam pengembangan 
karakter melalui permainan dan aktivitas olahraga yang menekankan pada kejujuran, kerja sama, percaya diri, tidak menyerah, komunikasi dan kemampuan mengatur strategi. Dengan prinsip pendidikan jasmani peserta didik ikut terlibat dalam mempraktekan kebiasaan hidup bersih yang diawali dengan kebersihan kuku, kaki, tangan dan mulut, menjaga kebersihan lingkungan dengan tidak membuang sampah sembarangan serta pola hidup sehat rajin berolahraga.

Hasil penelitian sejalan dengan penelitian yang dilakukan oleh Adalikwu dan Iorkpilgh (2013) bahwa para siswa belajar dengan menggunakan bahan ajar berkinerja baik dan lebih tinggi dari pada yang diajarkan tanpa bahan ajar. Oleh sebab itu dengan adanya buku ini dapat menjadi panduan/pendamping bagi guru dalam melaksanakan pembelajaran pendidikan jasmani bagi peserta didik, mengingat keterbatasan buku panduan pendidikan jasmani yang masih sangat sulit dijual di pasaran sehingga dalam menyajikan pembelajaran guru memiliki rencana yang mempermudah dalam mencapai tujuan pembelajaran. Jelasnya tujuan pembelajaran pendidikan jasmani di sekolah level bawah akan memiliki dampak signifikan bagi peserta didik ketika memasuki tahapan pendidikan selanjutnya. Dengan kondisi era digital dan milineal, perkembangan gadget yang sangat pesat menyebabkan kebiasaan sedenter pada anak-anak usia dini cukup mengkhawatirkan. Anak-anak usia dini difasilitasi dengan gadget yang menyebabkan ketergantungan sehingga menurunkan aktivitas fisik. Fogel et al (2010) menjelaskan perubahan perilaku pada anak-anak yang mendominasi aktivitas game digital berpotensi meningkatkan obesitas yang mempengaruhi kesehatan fisik telah menjadi masalah yang serius dan perlu ditemukan solusi. Karnik dan Kanekar (2012) sedentary (rendahnya aktivitas fisik) memicu tingginya angka obesitas anak usia dini. Merujuk paparan tersebut adalah peran guru dalam meracang pembelajaran pendidikan dirasa cukup penting untuk mengimbangi rendahnya aktivitas fisik anak di era digital ini.

\section{KESIMPULAN}

Berdasarkan hasil penelitian yang divalidasi oleh validator ahli materi, ahli pendidikan jasmani dan ahli pembelajaran anak usia dini dengan hasil keseluruhan penilaian validator dengan nilai 3.9 kategori "Baik". Dari hasil penilaian ahli tersebut dapat disimpulkan bahwa produk buku pembelajaran pendidikan jasmani bagi anak usia dini layak untuk digunakan sebagai buku pendamping dan panduan guru dalam proses pembelajaran pendidikan jasmani di jenjang pendidikan sekolah anak usia dini. Pada proses penelitian dengan validator ahli materi, ahli pembelajaran dan ahli pendidikan jasmani sangat sulit bertemu karena harus mencari waktu luang, apalagi ada ahli yang sedang tugas belajar S3 di Jakarta sehingga ditunggu kapan beliau kembali ke kampus dan saat pandemi Covid-19 pertemuan yang sifatnya tatap muka sangat terbatas untuk melakukan penelitian. Penelitian selanjutnya dapat dilakukan efektifitas buku ajar dalam pembelajaran pendidikan jasmani sehingga dapat melihat seberapa besar kebergunaan buku ajar ini pada PAUD.

\section{DAFTAR PUSTAKA}

Adalikwu, S., \& Iorkpilgh, I. (2013). The Influence of Instructional Materials on Academic Performance of Senior Secondary School Students in Chemistry in Cross River State. Global Journal of Educational Research, 12(1), 39-45. https://doi.org/10.4314/gjedr.v12i1.6. 
Best, J. R. (2010). Effects of physical activity on children's executive function: Contributions of experimental research on aerobic exercise. Developmental Review, 30(4), 331-351. https://doi.org/10.1016/j.dr.2010.08.001.

Clarke, G., \& Kinchin, G. D. (2005). Sport Education in Physical Education. Routledge London; New York: Routledge.

Dini, U. (2017). Penggunaan Gadget terhadap Kemampuan Interaksi Sosial. Jurnal Obsesi: Jurnal Pendidikan Anak Usia Dini Analisis, 1(1), 1-11. https://doi.org/10.31004/obsesi.v1i1.26.

Dyson, B. (2014). Quality physical education: A commentary on effective physical education teaching. Research Quarterly for Exercise and Sport, 85(2), 144-152. https://doi.org/10.1080/02701367.2014.904155.

Dyson, B. P., Linehan, N. R., \& Hastie, P. A. (2010). The Ecology of Cooperative Learning in Elementary Physical Education Classes. Journal of teaching in Physical Education, 29(2), 113-130. https://doi.org/10.1123/jtpe.29.2.113.

Fogel, V. A., Miltenberger, R. G., Graves, R., \& Koehler, S. (2010). The Effects of Exergaming on Physical Activity Among Inactive Children in a Physical Education Classroom. Journal of Applied Behavior Analysis, 43(4), 591-600. https://doi.org/10.1901/jaba.2010.43-591.

Herdiyana, A., \& Prakoso, G. P. W. (2016). Pembelajaran Pendidikan Jasmani yang Mengacu Pada Pembiasaan Sikap Fair Play dan Kepercayaan Pada Peserta Didik. $\begin{array}{llll}\text { Jurnal Olahraga } & \text { Prestasi, } & 12(1), & 15109 .\end{array}$ https://doi.org/10.21831/jorpres.v12i1.9498.

Hermawan, H. A. (2011). Multilateral: Konsep dan Aplikasi Olahraga Anak Usia Dini. Thesis. Universitas Negeri Yogyakarta: FIK.

Irwansyah, I. (2018). Pengembangan Buku Ajar Teori Tenis Meja Bagi Mahasiswa Kelas A 2016 Jurusan PJKR IKIP Budi Utomo Malang. JP.JOK (Jurnal Pendidikan Jasmani, Olahraga dan Kesehatan), 1(2), 47-59. https://doi.org/10.33503/jpjok.v1i2.166.

Karnik, S., \& Kanekar, A. (2012). Childhood obesity: A global public health crisis. International Journal of Preventive Medicine, 3(1), 1-7. https://doi.org/10.1201/b18227-3.

Pelana, R. (2014). Fun learning management for physical education, sport and health. Asian Social Science, 10(5), 85-90. https://doi.org/10.5539/ass.v10n5p85.

Pill, S. (2011). Teacher engagement with teaching games for understanding - game sense in physical education. Journal of Physical Education \& Sport/Citius Altius Fortius. 11(2), 115-123. 
Rosidah, R., \& Sumarni, S. (2017). Kelompok B di TK Negeri Pembina Indralaya Selatan. Jurnal Tumbuh Kembang, 4(2017), 45-51.

Sanusi, R., \& Widiyanto, W. (2018). Pengembangan model aquarobic exercise untuk pembakaran lemak pada overweight. Jurnal Keolahragaan, 6(2), 139-149. https://doi.org/10.21831/jk.v0i0.8560.

Schwamberger, B., \& Sinelnikov, O. (2015). Connecting physical education to out-ofschool physical activity through sport education. Journal of Physical Education, Recreation \& Dance, 86(9), 39-44. https://doi.org/10.1080/07303084.2015.1085344.

Suharnoko, F., \& Firmansyah, G. (2018). Pengembangan Model Pembelajaran Melompat Melalui Permainan Lompat Cermin untuk Siswa Sekolah Dasar. Jurnal SPORTIF: Jurnal Penelitian Pembelajaran, 4(2), 145. https://doi.org/10.29407/js_unpgri.v4i2.12169.

Surahman, F., \& Yeni, O. H. (2019). Pengembangan Buku Ajar Mata Kuliah Renang Bagi Mahasiswa Pendidikan Jasmani Kesehatan dan Rekreasi. Journal Sport Area, 4(1), 218-229. https://doi.org/10.25299/sportarea.2019.vol4(1).2413.

Undang-Undang Republik Indonesia. (2005). Sistem Keolahragaan Nasional. Dewan Perwakilan Rakyat dan Presiden Republik Indonesia. 